\title{
EquiLIBRIUM
}

Quarterly Journal of Economics and Economic Policy

2016 VOLUME 11 ISSUE 2, June

p-ISSN 1689-765X, e-ISSN 2353-3293

www.economic-policy.pl

Meluzín, T., \& Zinecker, M. (2016). Trends in IPOs: The Evidence from CEE Capital Markets. Equilibrium. Quarterly Journal of Economics and Economic Policy, 11(2), 327-341. DOI: http://dx.doi.org/10.12775/ EQUIL.2016.015

\author{
Tomáš Meluzín* \\ Marek Zinecker**
}

Brno University of Technology, Czech Republic

\section{Trends in IPOs: The Evidence from CEE Capital Markets***}

JEL Classification: $E 44 ; G 23 ; G 32$

Keywords: IPO; Going Public; Trends; Financial Markets; CEE

\begin{abstract}
The purpose of this paper is to investigate IPO developments across five CEE countries between 2003 and 2012. Using a wider range of methods and different data sets we intend to complement the previous research. Applying descriptive statistics, relevant local developments are analysed first before being compared with leading European markets (London Stock Exchange and Deutsche Börse). We also investigated the assumption that a growing market has an explanatory power for the accelerating IPO activity. For this purpose we performed a Spearman correlation analysis. The data were evaluated at the significance level of $\alpha=5 \%$. All CEE capital markets recorded strong dynamism over the observed period. All fundamental capital market parameters increase the attractiveness of individual capital markets, although their values lag behind developed European capital countries. The sole leader in the region is Poland with a flourishing IPO
\end{abstract}

(C) Copyright Institute of Economic Research

Date of submission: April 17, 2015; date of acceptance: November 12, 2015

*Contact: meluzint@ vutbr.cz, Brno University of Technology, Faculty of Business and Management, Kolejní 2906/4, CZ-612 00 Brno, Czech Republic

** Contact: zinecker@fbm.vutbr.cz, Brno University of Technology, Faculty of Business and Management, Kolejní 2906/4, CZ-612 00 Brno, Czech Republic

**** The research is financed by Internal Grant Agency of the Brno University of Technology. Name of the Project: Economic Determinants of Competitiveness of Enterprises in Central and Eastern Europe. Project Registration No. FP-S-15-2825. 
market. Our assumption that a growing market has a positive impact on IPO activities could not be supported by empirical evidence.

\section{Introduction}

Substantial academic literature devotes a significant amount of research to emphasising the importance of the financial system to economic growth (Balcerzak, 2009; Balcerzak \& Pietrzak, 2016). Kominek (2003) summarises recent empirical research (e.g. Schumpeter, 1911; Robinson, 1952; Lucas, 1988; Demirguc-Kunt \& Maksimovic, 1996; Levine \& Zervos, 1998; Rajan \& Zingales, 1998) and concludes that "well developed financial systems stimulate economic growth". Although the continental financial system is traditionally focused on banking (Balcerzak 2011), there is increasing interest in the stock markets and initial public offering (IPO) implementation (e.g. Pagano et al., 1998; Black \& Gilson, 1998; Chemmanur \& Fulghieri; 1999; Ritter \& Welch, 2002).

According to existing definitions, an IPO refers to the fact that a company offers its securities, in the strict sense of the word shares, to the public for the first time, and also enters the public organised securities market, represented most frequently by its stock exchange. The essential thing is that an IPO can only be used by issuers whose securities are not being traded on the public securities market at that time (Jenkinson \& Ljungqvist, 2001; Huyghebaert \& Van Hulle, 2006). According to the origin of the shares offered in an IPO, these authors distinguish between an IPO of primary shares, with the issuing of new shares and their placement on the public primary securities market, and an IPO of secondary shares, consisting of offering previously issued shares that have been traded only on the private secondary securities market.

The IPO markets of Central and Eastern Europe (CEE) have been empirically investigated by a relatively small number of academic studies. Peterle (2013) argues that, "apart from statistical data, there is almost no available academic research of IPO characteristics covering the entire CEE region, especially in the 2000s". She studied IPOs between 2000 and 2009, and concludes that capital market factors such as "market size, liquidity and market capitalisation to GDP do not have a decisive impact on IPO activities in the CEE region". On the other hand, "the attractiveness of the capital market as measured by annual stock index returns and by annual market and liquidity growth" may have been an incentive for decision-makers about IPOs in the observed period. Findings by Brzeszczynski (2014) show that "decisions about IPOs in Poland are strictly dependent on stock market 
phases and that IPOs tend to increase when share prices are rising and to decrease when they fall. This relationship is not simultaneous, as some lag effect can be observed that may be linked to the length of time taken by decision-makers".

Institutional and historical (i.e. qualitative) factors have been assessed by "soft" indicators such as perception of the capital market by enterprises, their confidence in the capital market and the quality of national regulations and structures. Roženský (2008) explored the conditions created by local CEE stock exchanges using the following indicators: the cost of going public, administrative requirements of issuers, the market segmentation of the particular stock exchange and, finally, its marketing and public relations. Groh et al. (2010) calculated composite indices to compare the attractiveness of 27 European countries for institutional investments in venture capital and private equity. They conclude that "the investor protection and corporate governance rules and the size and liquidity of its capital market are likewise a proxy for the professionalism of the financial community, for deal flow and exit opportunities".

Using a wider range of methods and different data sets, we intend to complement the previous research (Roženský, 2008; Peterle, 2013; Brzeszczynski, 2014) by considering IPO developments across five CEE countries between 2003 and 2012. Applying descriptive statistics, relevant local developments are analysed first before being compared with leading European markets.

\section{Research Methodology}

We investigated five CEE capital markets - Poland, the Czech Republic, Hungary, Slovenia and Austria (see also: Zineker et al., 2016; Fałdziński et al., 2016. Apart from Austria, all these countries share a similar historical background after World War II (see also: Pietrzak et al., 2017). All these countries turned to communism, built-up centrally planned economies and applied shock therapies in the early 1990s after the disintegration of the communist economic alliance. They all undertook different privatisation programmes during the first years of transition and a "prime example of this difference in attitudes is given by the organisation and development of the Czech and Polish stock exchanges" (Kominek, 2003).

The nature of this study is based on the theory and previous empirical research. All IPO indicators analysed in this paper have sufficient support in the financial academic literature (Roženský, 2008; Groh et al., 2010; Peterle, 2013; Brzeszczynski, 2014). 
The quantitative analyses of CEE IPO developments are based on evidence over the period from 2003 to 2012. Our sample includes enterprises that conducted an IPO on the Main Markets of CEE Stock Exchanges. Both the IPO and capital market data were obtained predominantly from Stock Exchange Fact Books, the Federation of European Securities Exchanges (FESE), the World Federation of Exchanges (WFE) and PwC (IPO Watch Europe).

The following steps were undertaken to analyse the quantitative data. Firstly, we performed a descriptive analysis in order to draw attention to certain specific issues existing on CEE IPO markets between 2003 and 2012. Next, we compared internal IPO characteristics on CEE markets with the empirical evidence on IPOs on the most developed EU capital markets (London SE and Deutsche Börse). We also investigated the assumption that a growing market has an explanatory power for the accelerating IPO activity. For this purpose, we performed a Spearman correlation analysis. The data were evaluated at the significance level of $\alpha=5 \%$. The entire statistical evaluation was performed by Statistica.CZ, Version 9. Descriptions of variables and the sources of data used are shown in Table 1. The results are explained and discussed with the conclusions of previous studies conducted under the conditions in force on developed capital markets.

Table 1. Analysed Variables

\begin{tabular}{|c|c|c|}
\hline & Data Sources & Calculation \\
\hline $\begin{array}{l}\text { Market Capitalisation } \\
\text { of Equities }\end{array}$ & \multirow{6}{*}{$\begin{array}{l}\text { Stock Exchange Fact Books, PwC } \\
\text { IPO Watch Europe, FESE, WFE }\end{array}$} & $\begin{array}{c}\text { in EUR m } \\
\text { (using yearly } \\
\text { closing dates) }\end{array}$ \\
\hline Index Returns & & $\begin{array}{l}\text { in } \%, \text { annual } \\
\text { change } \\
\text { (using yearly } \\
\text { closing dates) }\end{array}$ \\
\hline $\begin{array}{l}\text { Number of Listings } \\
\text { (IPOs) }\end{array}$ & & frequency \\
\hline Value of IPOs & & $\begin{array}{c}\text { in EUR m } \\
\text { (using yearly } \\
\text { closing dates) }\end{array}$ \\
\hline $\begin{array}{l}\text { Ownership Structure of } \\
\text { IPO companies }\end{array}$ & & in $\%$ \\
\hline $\begin{array}{l}\text { New (Primary) Shares } \\
\text { in IPO }\end{array}$ & & in $\%$ \\
\hline
\end{tabular}

Source: own processing. 


\section{Empirical Results}

\section{Equity Market Capitalisation}

In terms of size, the Warsaw Stock Exchange was dominant in the CEE region, holding a $39 \%$ share of market capitalisation, followed by the Vienna Stock Exchange with a $36 \%$ share of market capitalisation. The form and timing of privatisation fundamentally influenced market capitalisation in the 1990s. Roženský (2008) concludes that it was a positive influence in the Czech Republic and Hungary, though a negative influence in Poland because of the different manners of privatisation. In the second decade after the establishment of the local capital markets, more precisely between 2003 and 2012, the market capitalisation (in EUR) increased 2.5 times on the CEE market as a whole (see Table 2). The growth of the market was faster in comparison with established capital markets such as London, where market capitalisation increased by a factor of 1.5, or Frankfurt, where market capitalisation increased by a factor of 1.4. However, significant discrepancies can be observed in the development of individual markets (market capitalisation increased by a factor of 4.6 in Warsaw, 2.3 in Prague, 1.19 in Hungary, 0.87 in Slovenia and 1.79 in Austria). Since joining the EU (2004; Austria has been a member of the EU since 1995), all CEE capital markets amounted to 409,819 million EUR in the peak year of 2007 which represents only $16 \%$ of the market capitalisation of the London Stock Exchange and $28 \%$ of the market capitalisation of the Deutsche Börse. When we compare the CEE capital markets with developed capital markets in Western Europe, it must be noted that these markets are significantly smaller. Furthermore, in 2008, at the height of the financial and economic crisis, the decline recorded on this market was greater $(-57 \%)$ than on developed capital markets (UK $-49 \%$, Germany $-45 \%$ ). Changes in the value of market capitalisation were affected by three main factors - the financial and economic crisis of 2008, the appreciation/depreciation of local currencies, and the privatisation programme implemented by Polish governments (see also: Roženský, 2008). 
Table 2. Market Capitalisation - Domestic Issues (in EUR m), 2003-2012

\begin{tabular}{|c|c|c|c|c|c|c|c|c|}
\hline & PL & $\mathbf{C Z}$ & HU & SL & $\mathbf{A}$ & $\begin{array}{l}\text { Total } \\
\text { CEE }\end{array}$ & $\begin{array}{c}\text { London } \\
\text { SE }\end{array}$ & $\begin{array}{c}\text { Deutsche } \\
\text { Börse }\end{array}$ \\
\hline 2003 & 29,350 & 12,288 & 13,228 & 5,660 & 44,811 & 107,540 & $1,708,260$ & 802,224 \\
\hline 2004 & 51,888 & 21,720 & 21,040 & 7,115 & 64,577 & 169,579 & $2,071,775$ & 849,717 \\
\hline 2005 & 79,354 & 31,060 & 27,586 & 6,697 & 107,036 & 255,461 & $2,592,623$ & $1,019,171$ \\
\hline 2006 & 112,826 & 34,693 & 31,687 & 11,513 & 146,197 & 341,040 & $2,876,986$ & $1,241,963$ \\
\hline 2007 & 144,323 & 47,987 & 31,528 & 19,695 & 161,731 & 409,819 & $2,634,577$ & $1,439,955$ \\
\hline 2008 & 66,178 & 29,615 & 13,326 & 8,470 & 54,750 & 176,246 & $1,352,327$ & 797,063 \\
\hline 2009 & 105,157 & 31,265 & 21,093 & 8,462 & 79,511 & 249,102 & $2,008,188$ & 900,772 \\
\hline 2010 & 142,272 & 31,922 & 20,624 & 7,028 & 93,944 & 299,170 & $2,725,353$ & $1,065,713$ \\
\hline 2011 & 107,483 & 29,203 & 14,630 & 4,873 & 65,683 & 226,055 & $2,345,927$ & 912,420 \\
\hline 2012 & 134,755 & 28,193 & 15,742 & 4,911 & 80,429 & 268,124 & $2,643,991$ & $1,127,370$ \\
\hline Total & 973,586 & 297,946 & 210,484 & 84,424 & 898,669 & $2,502,138$ & $22,960,008$ & $\begin{array}{r}10,156,36 \\
8\end{array}$ \\
\hline Mean & 97,359 & 29,795 & 21,048 & 8,442 & 89,867 & 250,214 & $2,296,001$ & $1,015,637$ \\
\hline $\begin{array}{l}\text { Me- } \\
\text { dian }\end{array}$ & 106,320 & 30,337 & 20,832 & 7,072 & 79,970 & 252,282 & $2,469,275$ & 965,796 \\
\hline $\begin{array}{l}\text { Std. } \\
\text { Dev. }\end{array}$ & 37,434 & 8,590 & 6,753 & 4,193 & 36,514 & 83,296 & 470,868 & 197,730 \\
\hline Min. & 29,350 & 12,288 & 13,228 & 4,873 & 44,811 & 107,540 & $1,352,327$ & 797,063 \\
\hline Max. & 144,323 & 47,987 & 31,687 & 19,695 & 161,731 & 409,819 & $2,876,986$ & $1,439,955$ \\
\hline
\end{tabular}

Source: own calculations based on CEE Stock Exchange Group and its Capital Markets; Federation of European Securities Exchanges, Statistics \& Market Research; Roženský (2008); Warsaw Stock Exchange, Fact Books (2003-2013); World Federation of Exchanges, Statistics.

\section{Index Returns}

Assuming that a faster growing market promises higher subscription prices, it can be said that potential issuers will tend to go public on markets with higher rates of return. Differences in index returns can, for this reason, be essential during decision-making concerning IPOs. Spectacular annual index rate returns were recorded on all CEE stock capital markets during 2003-2012 and the Vienna, Budapest, Warsaw and Prague SEs in particular revealed significant potential for both investors and issuers (Table 3 ). 
Table 3. Change in Annual Index Returns (\%), 2003-2012

\begin{tabular}{lccccccc}
\hline & $\begin{array}{c}\text { WIG20 } \\
\text { Warsaw } \\
\text { SE }\end{array}$ & $\begin{array}{c}\text { PX } \\
\text { (CEESEG } \\
\text { Prague) }\end{array}$ & $\begin{array}{c}\text { BUX } \\
\text { (CEESEG } \\
\text { Budapest) }\end{array}$ & $\begin{array}{c}\text { SBI Top } \\
\text { (CEESEG } \\
\text { Ljubljana) }\end{array}$ & $\begin{array}{c}\text { ATX } \\
\text { (CEESEG } \\
\text { Vienna) }\end{array}$ & $\begin{array}{c}\text { FTSE } \\
\text { London } \\
\text { SE) }\end{array}$ & $\begin{array}{c}\text { DAX } \\
\text { (Deutsc } \\
\text { he } \\
\text { Börse) }\end{array}$ \\
\hline 2003 & 33.90 & 19.22 & 20.30 & - & 34.40 & 13.60 & 37.10 \\
2004 & 24.60 & 36.13 & 57.20 & 29.30 & 57.40 & 7.50 & 7.30 \\
2005 & 35.40 & 42.73 & 41.00 & 2.80 & 50.80 & 16.70 & 27.10 \\
2006 & 23.70 & 7.87 & 19.50 & 56.60 & 21.70 & 10.70 & 22.00 \\
2007 & 5.20 & 14.20 & 5.60 & 71.00 & 1.10 & 3.80 & 22.30 \\
2008 & -48.20 & -52.70 & -53.30 & -66.10 & -61.20 & -31.30 & -40.40 \\
2009 & 33.50 & 30.20 & 73.40 & 15.00 & 42.50 & 22.10 & 23.80 \\
2010 & 14.90 & 9.60 & 0.50 & -13.50 & 16.40 & 12.60 & 16.10 \\
2011 & -21.90 & -25.60 & -20.40 & -30.70 & -34.90 & -2.20 & -14.70 \\
2012 & 20.40 & 14.00 & 7.10 & 7.80 & 26.90 & 10.00 & 29.10 \\
Mean & 12.15 & 9.57 & 15.09 & 8.02 & 15.51 & 6.35 & 12.97 \\
Median & 22.05 & 14.10 & 13.30 & 7.80 & 24.30 & 10.35 & 22.15 \\
Std. & 25.85 & 27.35 & 34.92 & 39.88 & 35.90 & 14.06 & 22.32 \\
Dev. & -48.20 & -52.70 & -53.30 & -66.10 & -61.20 & -31.30 & -40.40 \\
Min. & 35.40 & 42.73 & 73.40 & 71.00 & 57.40 & 22.10 & 37.10 \\
Max. & & & & & & & \\
\hline
\end{tabular}

Source: own calculations based on CEE Stock Exchange Group and its Capital Markets; Federation of European Securities Exchanges, Statistics \& Market Research; Peterle (2013); Roženský (2008); Warsaw Stock Exchange, Fact Books (2003-2013); World Federation of Exchanges, Statistics

\section{CEE IPO Developments}

Table 4 gives an overview of market statistics of annual IPO time series. A total of 390 IPOs were listed during the period 2003-2012 on the EUregulated CEE primary capital markets which represents a $25.34 \%$ share of the whole EU-regulated market. The sum of the capital raised by the issuing companies was EUR 30,380 million, i.e. $11.22 \%$ of the new money raised through IPOs in Europe. The average IPO size was EUR 77.89 million and therefore amounted to $44.28 \%$ of the average in Europe as a whole. Prior to the financial and economic crisis (2008-2009), there was a remarkable boom in the annual number of IPOs which increased from 12 
in 2003 to 90 in 2007. The sharp decline in the number of IPOs in 2008 and 2009 was followed by a slight recovery of the market between 2010 and 2012.

Table 4. CEE IPO market statistics and a comparison with the EU-regulated markets, 2003-2012

\begin{tabular}{|c|c|c|c|c|c|c|c|c|}
\hline & 2003 & 2004 & \multicolumn{2}{|c|}{2005} & 2006 & 2007 & 2008 & 2009 \\
\hline $\begin{array}{l}\text { Number of } \\
\text { IPOs }\end{array}$ & 12 & 39 & \multicolumn{2}{|c|}{42} & 51 & 90 & 36 & 15 \\
\hline $\begin{array}{l}\text { Value of IPOs } \\
\text { (in EUR m) } \\
\text { Average IPO }\end{array}$ & 1,290 & 3,306 & \multicolumn{2}{|c|}{2,971} & 2,767 & 7,109 & 3,976 & 1,721 \\
\hline $\begin{array}{l}\text { Value } \\
\text { (in EUR m) }\end{array}$ & 107.5 & 84.8 & \multicolumn{2}{|c|}{70.7} & 54.3 & 79.0 & 110.4 & 114.7 \\
\hline \multirow[t]{2}{*}{$\begin{array}{l}\text { Capitalisation } \\
\text { of Equities } \\
\text { (in EUR m) }\end{array}$} & 107,540 & 169,579 & 255 & 461 & 341,040 & 409,819 & 176,246 & 249,102 \\
\hline & 2010 & \multicolumn{2}{|c|}{2011} & \multicolumn{2}{|c|}{2012} & Total CEE & \multicolumn{2}{|c|}{$\begin{array}{l}\text { CEE, \% of EU } \\
\text { regulated }\end{array}$} \\
\hline $\begin{array}{l}\text { Number of } \\
\text { IPOs } \\
\text { Value of }\end{array}$ & 41 & \multicolumn{2}{|c|}{48} & \multicolumn{2}{|c|}{16} & 390 & \multicolumn{2}{|c|}{25.34} \\
\hline $\begin{array}{l}\text { IPOs } \\
\text { (in EUR m) } \\
\text { Average IPO }\end{array}$ & 4,117 & \multicolumn{2}{|c|}{2,305} & \multicolumn{2}{|c|}{819} & 30,380 & \multicolumn{2}{|c|}{11.22} \\
\hline $\begin{array}{l}\text { Value } \\
\text { (in EUR m) }\end{array}$ & 100.4 & \multicolumn{2}{|c|}{48.0} & \multicolumn{2}{|c|}{51.2} & 77.89 & \multicolumn{2}{|c|}{44.28} \\
\hline $\begin{array}{l}\text { Capitalisation } \\
\text { of Equities } \\
\text { (in EUR m) }\end{array}$ & 299,170 & \multicolumn{2}{|c|}{226,055} & \multicolumn{2}{|c|}{268,124} & $2,502,138$ & \multicolumn{2}{|c|}{-} \\
\hline
\end{tabular}

Source: own calculations based on CEE Stock Exchange Group and its Capital Markets; Warsaw Stock Exchange, Fact Books (2003-2013); PWC - IPO Watch Europe (20032013); Federation of European Securities Exchanges, Statistics \& Market Research; World Federation of Exchanges, Statistics; Peterle (2013); Roženský (2008); Sieradzki (2013).

Table 4 further shows the market capitalisation of CEE stock exchanges over the last ten years. The sum of market capitalisation is EUR 2,502,138 million, which is still a significantly small value in comparison with the leading European markets. The market capitalisation of the CEE primary capital markets amounted to $25 \%$ of the Deutsche Börse market capitalisation and only $11 \%$ of the London Stock Exchange market capitalisation.

Warsaw's share of the EU-regulated market by number of issues increased to $21 \%$ in 2012 from $9 \%$ in 2003. This placed the Polish IPO market among the most active primary markets in Europe. On the other 
hand, the IPO market share by offering value experienced significant growth only between 2008 and 2010. The 8\% average share of offering value on the EU-regulated market, despite a 12 percentage points average increase in the number of IPOs, reflects the number of relatively low-value IPOs Warsaw hosted on its Main Market.

Table 5. Distribution of IPOs in the CEE region (EU Regulated), 2003-2012

\begin{tabular}{ccccccccc}
\hline & PL & CZ & HU & SL & A & $\begin{array}{c}\text { Total } \\
\text { CEE }\end{array}$ & $\begin{array}{c}\text { Poland, \% of } \\
\text { CEE }\end{array}$ & $\begin{array}{c}\text { Poland, \% of EU } \\
\text { regulated }\end{array}$ \\
\hline 2003 & 6 & 0 & 0 & 0 & 6 & 12 & 50.00 & 8.82 \\
2004 & 36 & 1 & 1 & 0 & 1 & 39 & 92.31 & 24.16 \\
2005 & 35 & 0 & 0 & 0 & 7 & 42 & 83.33 & 15.28 \\
2006 & 38 & 2 & 3 & 2 & 6 & 51 & 74.51 & 15.14 \\
2007 & 81 & 2 & 0 & 1 & 6 & 90 & 90.00 & 22.50 \\
2008 & 33 & 1 & 1 & 1 & 0 & 36 & 91.67 & 28.70 \\
2009 & 13 & 0 & 2 & 0 & 0 & 15 & 86.67 & 31.71 \\
2010 & 34 & 1 & 6 & 0 & 0 & 41 & 82.93 & 26.15 \\
2011 & 38 & 1 & 6 & 1 & 2 & 48 & 79.17 & 32.20 \\
2012 & 16 & 0 & 0 & 0 & 0 & 16 & 100.00 & 20.51 \\
Total & 330 & 8 & 19 & 5 & 28 & 390 & 84.62 & 21.44 \\
\hline
\end{tabular}

Source: own calculations based on CEE Stock Exchange Group and its Capital Markets; Warsaw Stock Exchange, Fact Books (2003-2013); PWC - IPO Watch Europe (20032013); Federation of European Securities Exchanges, Statistics \& Market Research; World Federation of Exchanges, Statistics; Peterle (2013); Roženský (2008); Sieradzki (2013).

Table 6. Value of IPOs in the CEE region in EUR m (EU Regulated), 2003-2012

\begin{tabular}{ccccccccc}
\hline & PL & CZ & HU & SL & A & Total CEE & Poland, \% of CEE & $\begin{array}{c}\text { Poland, } \\
\text { \% of EU } \\
\text { regulated }\end{array}$ \\
\hline 2003 & 287.89 & 0.00 & 0.00 & 0.00 & $1,002.00$ & $1,290.00$ & 22.32 & 5.32 \\
2004 & $3,124.05$ & 174.90 & - & 0.00 & 7.00 & $3,306.00$ & 94.50 & 12.95 \\
2005 & $1,808.64$ & 0.00 & 0.00 & 0.00 & $1,162.00$ & $2,971.00$ & 60.88 & 4.04 \\
2006 & $1,085.30$ & 216.88 & - & - & $1,465.00$ & $2,767.00$ & 39.22 & 1.90 \\
\hline
\end{tabular}


Table 6 continued

\begin{tabular}{ccccccccc}
\hline & PL & CZ & HU & SL & A & $\begin{array}{c}\text { Total } \\
\text { CEE }\end{array}$ & $\begin{array}{c}\text { Poland, \% } \\
\text { of CEE }\end{array}$ & $\begin{array}{c}\text { Poland, } \\
\text { \% of EU } \\
\text { regulated }\end{array}$ \\
\hline 2007 & $5,096.87$ & 90.16 & 186.00 & 309.00 & $1,427.00$ & $7,109.00$ & 71.70 & 7.81 \\
2008 & $2,235.40$ & $1,581.14$ & 5.00 & 154.00 & 0.00 & $3,976.00$ & 56.23 & 19.05 \\
2009 & $1,701.23$ & 0.00 & 19.80 & 0.00 & 0.00 & $1,721.00$ & 98.85 & 39.20 \\
2010 & $4,005.76$ & 73.21 & 38.00 & 0.00 & 0.00 & $4,117.00$ & 97.30 & 16.98 \\
2011 & $1,931.26$ & 7.90 & 0.00 & 0.00 & 366.00 & $2,305.00$ & 83.78 & 7.82 \\
2012 & 818.60 & 0.00 & 0.00 & 0.00 & 0.00 & 819.00 & 100.00 & 8.59 \\
\hline Total & $22,095.01$ & $2,144.18$ & 248.80 & 463.00 & $5,429.00$ & $30,380.00$ & 72.73 & 8.16 \\
\hline
\end{tabular}

Source: own calculations based on CEE Stock Exchange Group and its Capital Markets; Warsaw Stock Exchange, Fact Books (2003-2013); PWC - IPO Watch Europe (2003 -2013); Federation of European Securities Exchanges, Statistics \& Market Research; World Federation of Exchanges, Statistics; Peterle (2013); Roženský (2008); Sieradzki (2013).

Table 7 shows the degree to which national governments have used the capital market as a tool of privatisation over the last ten years. Privatisation via IPOs (PIPOs) was executed on four CEE capital markets. WSE continued to dominate the number of privatisation IPOs on the CEE market (20 cases of privatisation) followed by Austria ( 5 cases of privatisation), Hungary and Slovenia ( 1 case of privatisation on each market). Private IPO levels in the region were more than $93 \%$ in terms of numbers between 2002 and 2012.

In view of its extraordinary importance among the CEE capital markets, we also focused on IPO types conducted on the Warsaw SE. Table 8 presents their distribution based on the proportion of primary (new) and secondary shares in IPOs. We can therefore conclude that IPOs with only primary stocks in Poland prevailed with a share higher than 50\%, however this share was 20 percentage points lower than indicated for continental Europe (Kim \& Weisbach, 2006). 
Table 7. Ownership Structure of IPO companies (EU Regulated), 2003-2012

\begin{tabular}{lcccccc}
\hline & PL & CZ & HU & SL & A & Total CEE \\
\hline Privatisation IPOs (PIPOs) & 20 & 0 & 1 & 1 & 5 & 27 \\
\% in Total & 6.06 & 0.00 & 5.26 & 20.00 & 17.86 & 6.92 \\
Private Go Public & 310 & 8 & 18 & 4 & 23 & 363 \\
$\%$ in Total & 93.94 & 100.00 & 94.74 & 80.00 & 82.14 & 93.08 \\
\hline
\end{tabular}

Source: own calculations based on CEE Stock Exchange Group and its Capital Markets; Warsaw Stock Exchange, Fact Books (2003-2013); Peterle (2013); Roženský (2008); Sieradzki (2013).

Table 8. Poland - Distribution of IPO Shares (EU Regulated), 2003-2012

\begin{tabular}{lccc}
\hline & $\begin{array}{c}\text { Offering } \\
\text { Value }\end{array}$ & $\begin{array}{c}\text { Value of New (Primary) Shares in } \\
\text { IPO }\end{array}$ & $\begin{array}{c}\text { \% of New (Primary) } \\
\text { Shares in IPO }\end{array}$ \\
\hline 2003 & 287.89 & 273.05 & 94.85 \\
2004 & $3,124.05$ & 285.85 & 9.15 \\
2005 & $1,808.64$ & $1,359.95$ & 75.19 \\
2006 & $1,085.30$ & 638.14 & 58.80 \\
2007 & $5,096.87$ & $4,296.59$ & 84.30 \\
2008 & $2,235.40$ & 878.42 & 39.30 \\
2009 & $1,701.23$ & $1,684.76$ & 99.03 \\
2010 & $4,005.76$ & 323.37 & 8.07 \\
2011 & $1,931.26$ & 374.50 & 19.39 \\
2012 & 818.60 & 289.62 & 35.38 \\
Mean & $2,209.50$ & $1,040.43$ & 52.35 \\
Median & $1,869.95$ & 506.32 & 49.05 \\
Std. Dev. & $1,406.70$ & $1,182.69$ & 33.08 \\
Min. & 287.89 & 273.05 & 8.07 \\
Max. & $5,096.87$ & $4,296.59$ & 99.03 \\
\hline
\end{tabular}

Source: own calculations based on Warsaw Stock Exchange, Fact Books (2003-2013). 


\section{Conclusions}

Our results indicate strong dynamism on all CEE capital markets between 2003 and 2012. The growth of these markets evaluated by market capitalisation was significantly faster in comparison with developed capital markets in Western Europe, especially before 2008. First and foremost, Poland has outperformed all other countries and replaced the former local leader, Austria.

When we consider annual stock index returns, the favourable development of these indicators is another sign of the dynamism recorded on CEE stock exchanges. This could be seen as a signal of increasing market attractiveness for both investors and potential issuers (IPO candidates) and thereby accelerate IPO activity. High average values of annual stock index returns on all CEE stock capital markets were outstanding in comparison with the developed capital markets and were, therefore, another factor increasing CEE capital market attractiveness.

However, despite the promising development of fundamental capital market parameters, our evidence supports the conclusions made by Peterle (2013) that all CEE capital markets, including the Warsaw SE, are characterised by their "lower quality" as compared with developed EU markets. Using Spearman correlation analysis, we tested our assumption that a growing market has an explanatory power for the accelerating IPO activity, particularly in Poland. This assumption could not be supported by empirical evidence, which implies that although IPO activity was increasing, especially before 2008, no relationship could be identified between the increasing number of primary issues and indicators of size on capital markets. This confirms the findings of Peterle (2013), namely that "capital market factors do not have a decisive impact on IPO activities in the CEE region", although certain capital market parameters reflecting increasing capital market attractiveness could be an important IPO accelerator. Roženský (2008) concluded, on the basis of descriptive statistics for the CEE capital markets between 2003 and 2008, that the contribution of primary emissions to market capitalisation growth cannot be considered essential in view of the small value of new issues and their low performance: "Increasing market capitalisation on the Budapest, Warsaw and Prague SEs is more related to stock index returns". Roženský (2008) also points out the low liquidity of the stock of new listed companies in Poland between 2003 and 2007: "Only few new listed companies contributed significantly to market turnover. Moreover, these companies were either privatised or parallel listed by their foreign shareholders." 
To sum up our conclusions, all CEE capital markets recorded strong dynamism over the observed period. All fundamental capital market parameters increase the attractiveness of individual capital markets, although their values lag behind developed European capital countries. The unambiguous leader in the region is Poland with a flourishing IPO market. Our assumption that a growing market has a positive impact on IPO activities could not be supported by empirical evidence.

A further research on the issues addressed in this paper assumes, firstly, a modification of the explored variables (a combination of macroeconomic, institutional and capital market factors), secondly, an analysis of the individual markets based on both quantitative and qualitative models, and finally a continuous extension of the time series.

\section{References}

Balcerzak, A. P. (2009). Effectiveness of the Institutional System Related to the Potential of the Knowledge Based Economy. Ekonomista, 6.

Balcerzak, A. P. (2011). Structure of Financial Systems and Development of Innovative Enterprises with High Grow Potential. Prace Naukowe Uniwersytetu Ekonomicznego we Wroctawiu. Global Challenges and Politics of the European Union - Consequences for the "New Member States", 59.

Balcerzak, A. P., \& Pietrzak, M. B. (2016). Quality of Institutions for Knowledgebased Economy within New Institutional Economics Framework. Multiple Criteria Decision Analysis for European Countries in the Years 2000-2013. Economics \& Sociology, 9(4). DOI: 10.14254/2071-789X.2016/9-4/4.

Black, B. S., \& Gilson, R. J. (1998). Venture Capital and the Structure of Capital markets: Banks versus stock markets. Journal of Financial Economics, 47(3). DOI: http://dx.doi.org/10.2139/ssrn.46909.

Brzeszczynski, J. IPOs in Emerging Markets. Retrieved from http://www.qfinance. com/financing-best-practice/ipos-in-emerging-markets? full (16.02.2014).

CEE Stock Exchange Group and its Capital Markets. Budapest, Ljubljana, Prague, Vienna: CEE Stock Exchange Group. Retrieved from http://www.ceeseg.com (10.05. 2014).

Chemmanur, T. J., \& Fulghiery, A. (1999). Theory of the Going-Public Decision. Review of Financial Studies, 12(2). DOI: http://dx.doi.org/10.1093/rfs/12.2. 249.

Demirguc-Kunt, A., \& Maksimovic, V. (1996). Financial Constraints, Uses of Funds and Firm Growth: an InternationalCcomparison. Policy Research Working Paper, 1671, Washington D.C., World Bank. 
Fałdziński, M., Balcerzak, A. P., Meluzín, T., Pietrzak, M. B., \& Zinecker, M. (2016). Cointegration of Interdependencies Among Capital Markets of Chosen Visegrad Countries and Germany. In A. Kocourek \& M. Vavrousek (Eds.). $34^{\text {th }}$ International Conference Mathematical Methods in Economics MME 2016 Conference Proceedings. Liberec: Technical University of Liberec.

Federation of European Securities Exchanges, Statistics \& Market Research. Retrieved from http://www.fese.eu (10.02.2014).

Groh, A., P., Von Liechtenstein, H., \& Lieser, K. (2010). The European Venture Capital and Private Equity Country Attractiveness Indices. Journal of Corporate Finance, 16(2). DOI: http://dx.doi.org/10.1016/j.jcorpfin.2009.09.003.

Huyghebaert, N., \& Van Hulle, C. (2006). Structuring the IPO: Empirical evidence on the portions of primary and secondary shares. Journal of Corporate Finance, 12(2). DOI: http://dx.doi.org/10.1016/j.jcorpfin.2005.01.001.

Jenkinson, T., \& Ljungqvist, A. (2001). Going Public: The Theory and Evidence on How Companies Raise Equity Finance. Oxford: Oxford University Press.

Kim, W., \& Weisbach, M. S. (2008). Motivations for Public Equity Offers: An International Perspective. Journal of Financial Economics, 87(2). DOI: http://dx.doi.org/10.1016/j.jfineco.2006.09.010.

Kominek, Z. (2003). Stock Markets and Industry Growth: an Eastern European Perspective. Working Paper, 81, London, EBRD.

Levine, R., \& Zervos, S. (1998). Stock Markets and Economic Growth. American Economic Review, 88.

Lucas, R. E. (1988). On the Mechanics of Economic Development. Journal of Monetary Economics, 22.

Pagano, M., Panetta, F., \& Zingales, L. (1998). Why do Companies Go Public: An Empirical Analysis. Journal of Finance, 53(1). DOI: http://dx.doi.org/10. 1111/0022-1082.25448.

Peterle, P. (2013). Internal Characteristics and External Factors of IPO Activities in Central and Eastern Europe: Empirical Analysis and Comparison. Working Paper. Ljubljana: Faculty of Economics of the University of Ljubljana.

Pietrzak, M. B., Fałdziński, M., Balcerzak' A. P., Meluzín, T., \& Zinecker, M. (2017). Short-term Shocks and Long-term Relationships of Interdependencies Among Central European Capital Markets. Economics \& Sociology, 10(1). DOI: 10.14254/2071-789X.2016/10-1/5.

PwC, IPO Watch Europe 2003-2012. Retrieved from http://www.pwc.co.uk (10.05.2014).

Rajan, R. G., \& Zingales, L. (1998). Financial Dependence and Growth. American Economic Review, 88.

Robinson, J. (1952). The Generalization of the General Theory. The Role of Interest and Other Essays. London: Macmillan.

Ritter, J. R., \& Welch, I. (2002). A Review of IPO Activity, Pricing, and Allocations. Journal of Finance, 57(4). DOI: http://dx.doi.org/10.1111/1540$\underline{6261.00478}$. 
Schumpeter, J. (2012). A Theory of Economic Development. Cambridge: Harvard University Press, Massachusetts.

Roženský, V. (2008). IPO na středoevropských akciových trzích. Thesis. Praha: Univerzita Karlova v Praze, Fakulta sociálních věd.

Sieradzki, R. (2013). Does It Pay to Invest in IPOs? Evidence from the Warsaw Stock Exchange. Working Paper, 139, Warsaw: National Bank of Poland.

Zinecker, M., Balcerzak, A. P., Fałdziński, M., Meluzín, T., \& Pietrzak, M. B. (2016). Application of DCC-GARCH Model for Analysis of Interrelations Among Capital Markets of Poland, Czech Republic and Germany. In Proceedings of the International Scientific Conference Quantitative Methods in Economics Multiple Criteria Decision Making XVIII. Vratna: Letra Interactive.

Warsaw Stock Exchange, Fact Books 2003 - 2013. Retrieved from http://www.gpw.pl/fact_books (10.08.2014).

World Federation of Exchanges, Statistics. Retrieved from http://www.worldexchanges.org (10.08.2014). 